Kansas State University Libraries

New Prairie Press

Academic Chairpersons Conference

33rd Academic Chairpersons Conference,

Proceedings

Charleston, SC

\title{
Leadership around the clock: Balancing caregiving and chairing
}

\author{
Nadine A. Hartig \\ Radford University, nhartig@radford.edu \\ Kenna Colley \\ Radford University, kcolley@radford.edu \\ Melissa Grim \\ Radford University, mgrim@radford.edu
}

Follow this and additional works at: https://newprairiepress.org/accp

Part of the Educational Leadership Commons, and the Higher Education Administration Commons (c) (i) (2)

This work is licensed under a Creative Commons Attribution-Share Alike 4.0 License.

\section{Recommended Citation}

Hartig, Nadine A.; Colley, Kenna; and Grim, Melissa (2016). "Leadership around the clock: Balancing caregiving and chairing," Academic Chairpersons Conference Proceedings. https://newprairiepress.org/ accp/2016/Faculty/2

This Event is brought to you for free and open access by the Conferences at New Prairie Press. It has been accepted for inclusion in Academic Chairpersons Conference Proceedings by an authorized administrator of New Prairie Press. For more information, please contact cads@k-state.edu. 


\section{Full Text Description of Session}

What is the focus of the presentation and how is it relevant to chairpersons? The focus of the presentation is supporting and offering strategies to anyone balancing multiple roles and needs of different people. This is particularly relevant to chairs who may feel responsible for little people at home, aging parents, and a whole staff of people with competing needs and interests. This may also help the chair better understand how to help the faculty member struggling with work-life balance.

What recommendations will be made to the chairpersons? Interventions for self and others will be provided. Collective knowledge will be generated in the presentation and shared with the group.

Objectives:

1. All participants will experience the healing quality of universality: knowing they are not alone in balancing many roles. The presenters are committed to creating a safe environment for participants to share and learn.

2. Participants will be able to identify three useful strategies for managing conflicting demands on their time and energy, specific to the developmental level of the needs (e.g. toddlers versus adolescents versus elderly parents)

3. Participants will learn the definitions of depletion fatigue, redemptive regret, boundary violations and be able to identify these concepts in their own lives.

4. Participants will learn three new strategies for developing self-compassion and practice them at least once in the session.

\section{Description:}

Environment:

We request a room with tables. On each table, a sign will designate an age group e.g. infants, toddlers, elementary children, middle school children, adolescents, college age children, elderly parents, children with special needs, other.

We will ask participants to choose to sit at the table that fits the profile of their caregiving duties. In theory, we are hoping to group parents of teens at one table, etc.

Schedule and Description of Presentation:

20 minutes: Introductions of presenters and participants at each table. Activity: top 2 joys and stressors of caregiving and chairing. 
20 minutes: Brief didactic presentation on career demands, caregiving demands, role strain, depletion fatigue, and the chaos of it all. After presentation, each table will share their strategies for dealing with these issues.

20 minutes: Brief didactic presentation on self-compassion and harnessing the power of acceptance Activity: Letter writing to self. (self-compassion activity, based on "letter from your wiser self" intervention)

15 minutes: Open sharing in tables for stressors of specifics within each developmental stage.

15 minutes: Sharing as a large group, from each table. Discussion about mentoring possibilities.

15 minute: Sharing time from each table. Q\&A. Collection of notes from each table for compilation. Mentoring sign up.

\section{5 minutes}

**We will be particularly sensitive to diverse families and the special impact these situations place on caregivers. For example, a woman of color may feel extra burden to be physically present for her children in a community where she is worried they will not be accepted. The first goal of this session is to establish safety and universality within the group. 